\title{
MEMBERS OF THE SOCIETY.
}

\author{
JANUARY I, I899.
}

Life members are designated by *.

1892, Nov. ABbe, Cleveland, M.A., Ph.D., LL.D.; Member of the National Academy of Sciences ; F.R.A.S.; Member of the Astronomische Gesellschaft ; Editor of the Monthly Weather Review ; Professor of Meteorology, U. S. Weather Bureau ; Professor of Meteorology, Columbian University, Washington, D. C.; U. S. Weather Bureau.

1891, Nov. Aley, Robert Judson, M.A., Ph.D. (Pennsylvania) ; Member of the London Mathematical Society; Member of the Deutsche Mathematiker-Vereinigung ; Professor of Mathematics Indiana University, Bloomington, Ind. 632 North College Avenue.

1897, Dec. Allen, JosepH, M.A.; Instructor in Mathematics, College of the City of New York. 17 Lexington Avenue, New York, N. Y.

1892, Apr. Annis, Burleigh Smart, M.A. Hartford, Conn.

1891, June Baker, Alfred, M.A.; Member of the Société Mathématique de France ; Professor of Mathematics, University of Toronto, Toronto, Canada.

1891, Feb. Baker, Arthur Latham, C.E., Ph.D; Professor of Mathematics, University of Rochester, Rochester, N. Y. 28 Strathallan Park.

1898, Feb. Baker, Henry Frederick, M.A.; F.R.S.; Member of the London Mathematical Society ; Fellow of the Cambridge Philosophical Society ; Fellow and Lecturer of St. John's College, Cambridge, England. \& Belvoir Terrace, Trumpington Road.

1891, Apr. Baker, Marcus, M.A.; Cartographer, U. S. Geological Survey, Washington, D. C.

1894, Mar. Baldwin, JAmes Robert, M.A.; Teacher of Mathematics, Davenport Business College, Davenport, Iowa. 305 East 11th Street.

1894, Oct. Barnum, Charlotte Cynthia, B.A., Ph.D. (Yale); 144 Humphrey Street, New Haven, Conn.

1892, Apr. Barton, Samuel Marx, B.A., Ph.D.; Professor of Mathematics, University of the South, Sewanee, Tenn.

1891, Apr. Bass, EDgar Wales, Graduate of the U. S. Military Academy; Colonel U. S. Army, retired; 524 Fifth Avenue, New York, N. Y. 
Vate of

Admission.

1891, Apr. Beman, Wooster Woodruff, M.A.; Member of the London Mathematical Society; Member of the Deutsche Mathematiker-Vereinigung; Professor of Mathematics, University of Michigan, Ann Arbor, Mich. 813 East Kingsley Street.

1897, Dec. Benner, Henry, M.S., Ph.D. (Erlangen); Professor of Mathematics, Albion College, Albion, Mich.

1897, Feb. Berry, Arthur, M.A.; Member of the London Mathematical Society ; F.R.A.S.; Fellow and Assistant Tutor in Mathematics, King's College, Cambridge, England.

1891, Dec. Blake, Edwin Mortimer, E.M., Ph.D. (Columbia); 230 Washingtor Avenue, Brooklyn, N. Y.

1892, Apr. Bôcher, MAхıмe, B.A., Ph.D. (Göttingen); Associate Editor of the Annals of Mathematics; Assistant Professor of Mathematics, Harvard University, Cambridge, Mass. 12 Shepard Street.

1891, Nov. Bolza, OskaR,!Ph.D. (Göttingen); Member of the Deutsche Mathematiker-Vereinigung ; Professor of Mathematics, University of Chicago, Chicago, Ill.

1898, Dec. Bouton, Charles Leonard, M.Sc., M.A., Ph.D. (Leipzig); Instructor in Mathematics, Harvard University, Cambridge, Mass.

1891, June Bowser, EDward Albert, C.E., LL.D.; Professor of Mathematics, Rutgers College, New Brunswick, N. J.

1898, Feb. Breuke, Wilmiam Charles, B.Sc.; Instructor in Mathematics and Astronomy, Illinois University, Champaign, Ill.

1891, June Brooks, JoHN MrLton, M.A.; Instructor in Mathematics, John C. Green School of Science, Princeton University, Princeton, N. J. P. O. Box 71 .

1893, Dec. Brown, Edward Leroy, M.A.; Head Teacher of Mathematics, North Side High School, Denver, Colo. 3030 Homer Boulevard, Station $B$.

1892, Feb. Brown, Ernest WilltaM, M.A., D.Sc. (Cambridge); F.R.S.; Member of the London Mathematical Society ; Fellow of the Cambridge Philosophical Society; F.R.A.S.; Professor of Applied Mathematics, Haverford College, Haverford, Pa.

1891, June Bullis, Abram Rogkrs, B.Sc., B.C.E. Macedon, Wayne County, N. Y.

1895, Mar. BurnhaM, Alton Cyrel, B.Sc.; Instructor in Mathematics, University of Illinois, Urbana, Ill. 903 California Avenue.

1891, Apr. Byerly, William Elwood, M.A., Ph.D. (Harvard); Professor of Mathematics, Harvard University, Cambridge, Mass. 39 Hammond Street. 
1891, June CAIN, WilliaM, C.E., M.A.; Professor of Mathematics, University of North Carolina, Chapel Hill, N. C.

1897, Oct. Capron, Paur, M.A. 4 Gorham Street, Cambridge, Mass.

1896, Apr. Chace, Arnold Buffum, M.A., D.Sc. (Brown); Valley Falls, R. I.

1891, May Chandere, Charles Henry, M.A.; Professor of Mathematics, Ripon College, Ripon, Wis.

1891, Nov. Chapman, Charles Hiram, B.A., Ph.D. (Johns Hopkins); President of the University of Oregon, Eugene, Oregon.

1895, Nov. Chessin, Alexander S., Ph.D. 280 Amsterdam Avenue, New York, N. Y.

1895, Nov. Chittenden, J. Brace, B.Sc., M.A., Ph.D. (Königsberg); Tutor in Mathematics, Columbia University, New York, N. Y.

1891, Apr. Clark, JoHN EmoRy, M.A.; Professor of Mathematics, Yale University, New Haven, Conn. 445 Orange Street.

1896, Sept. Clutz, Frank Hollinger, B.A., Ph.D. (Johns Hopkins); Professor of Mathematics and Astronomy, Carthage College, Carthage, Ill. P. O. Box 201.

1893, Feb. Cohen, Abraham, B.A., Ph.D. (Johns Hopkins); Associate in Mathematics, Johns Hopkins University, Baltimore, Md.

1893, Oct. Colaw, John Marvin, M.A.; Associate Editor of the American Mathematical Monthly; Principal of the Monterey High School, Monterey, Va.

1891, Apr. Cole, Frank Nelson, B.A., Ph.D. (Harvard); Editor of the Bulletin of the American Mathematical Society; Professor of Mathematics, Columbia University, New York, N. Y.

1898, Feb. Comstock, Elting Houghtaling, B.Sc.; Fellow in Mathematics, University of Chicago, Chicago, Ill. Graduate Hall.

1892, Oct. Conant, Levi Leunard, M.A., Ph.D.; Editor of the Journal of the Polytechnic Institute; Associate Professor of Mathematics, Worcester Polytechnic Institute, Worcester, Mass.

1891, Apr. Crawley, Edwin Schofield, B.Sc., Ph.D.; Assistant Professor of Mathematics, University of Pennsylvania, Philadelphia, Pa.

1891, Dec. CunninghaM, Susan J.; Professor of Mathematics and Astronorny, Swarthmore College, Swarthmore, Pa.

1891, June Davies, John Eugene, M.A., M.D., LL.D.; Professor of Electricity and Magnetism and Mathematical Physics, University of Wisconsin, Madison, Wis. 523 N. Carroll Street. 
Admission.

1891, Apr. Davis, Ellery Williams, B.Sc., Ph.D. (Johns Hopkins); Professor of Mathematics, University of Nebraska, Lincoln, Neb.

1891, Oct. Davis, John WoodBridge, C.E., Ph.D.; Principal of the Woodbridge School, 523 W. 173d Street, New York, N. Y.

1891, Apr. Davis, Nathaniel French, M.A., LL.D.; Professor of Pure Mathematics, Brown University, Providence, R. I. 159 Brown Street.

1891, May Delong, Ira Mitcheld, M.A., Professor of Mathematics, University of Colorado, Boulder, Colo. 1805 12th Street.

1895, Jan. DeLury, Alfred Tennyson, B.A.; Lecturer in Mathematics, University of Toronto, Toronto, Can.

1892, Jan. Dennetr, William Sawyer, B.A., M.D. 8 E. 49 th Street, New York, N. Y.

1896, Nov. Drckson, Leonard Eugene, B.Sc., M.A., Ph.D. (Chicago) ; Instructor in Mathematics, University of California, Berkeley, Cal. P. O. Box 3 .

1893, Dec. Doolithle, CharLes L., C.E., D.Sc.; Member of the Astronomische Gesellschaft ; Professor of Mathematics and Astronomy and Director of the Flower Observatory, University of Pennsylvania, Philadelphia, $\mathrm{Pa}$.

1897, Apr. Dowling, Linn aus Wayland, Ph.D. (Clark); Assistant Professor of Mathematics, University of Wisconsin, Madison, Wis. $231 \mathrm{~W}$. Gilman Street.

1891, Apr. Durell, Fletcher, B.A., Ph.D.; Master in Mathematics, Lawrenceville School. Lawrenceville, N. J.

1891, Apr. Durfee, William PitT, B.A., Ph.D. (Johns Hopkins); Professor of Mathematics and Dean of the Faculty, Hobart College, Geneva, N. Y. 645 Main Street.

1891, Apr. Echols, William Holding, B.Sc.; Editor of the Annals of Mathematics; Professor of Mathematics, University of Virginia, Charlottesville, Va.

1891, Apr. EdDy, Henry Turner, M.A., C.E., Ph.D., LL.D.; Professor of Engineering and Mechanics, University of Minnesota, Minneapolis, Minn. 916 Sixth Street, S. $E$.

1896, Dec. Fdmondson, Thomas William, B.A., Ph.D. (Clark) ; Assistant Professor of Physics, New York University, University Heights, New York, N. Y.

1897, Feb. Erescand, John, B.Ph., Ph.D. (Johns Hopkins) ; Professor of Mathematics, Thiel College, Greenville, Pa.

1894, June Eimbeck, William ; Assistant in the U. S. Coast and Geodetic Survey, Washington, D. C.

1898, Feb. * Elliotr, Edwin BaIley, M.A.; Vice-President of the London Mathematical Society; F.R.S.; F.R.A.S.; Waynflete Professor of Pure Mathematics and Fellow of Magdalen College, Oxford, England. 4 Bardwell Road. 
Admission.

1894, Mar. Ellwoon, John Kelley, M.A.; Principal of the Colfax School, Pittsburg, Pa. Woodlawn Avenue.

1891, May Ely, Achsaf Mount, B.A.; Professor of Mathematics, Vassar College, Poughkeepsie, N. Y.

1896, Nov. Emch, ARnold, M.Sc., Ph.D. (Kansas) ; Professor of Graphic Mathematics, Kansas State Agricultural College, Manhattan, Kansas.

1898, Apr. Engberg, Carl Christian, B.Sc, M.A.; Fellow in Mathematics, University of Nebraska, Lincoln, Neb.

1892, Mar. Engler, Edmund Arthur, M.A., Ph.D.; Professor of Mathematics and Descriptive Geometry and Dean of the School of Engineering. Washington University, St. Louis, Mo.

1898, Oct. EscotT, EDWARD BRIND, B.Sc., M.Sc.; Instructor in the Union High School, Grand Rapids, Mich. 126 Turner Street.

1891, May Esty, William Cole, LL.D.; Professor of Mathematics and Astronomy, Amherst College, Amherst, Mass.

1896, Jan. Evans, Henry Brown, M.E.; Instructor in Astronomy, University of Pennsylvania, Philadelphia, Pa. Flower Astronomical Obse, vatory, Upper Darby, Pa.

1891, May Fields, John Charles, Ph.D. (Johns Hopkins); Member of the Société Mathématique de France; 10 Burlington Street, Hamilton, Canada.

1891, May Fine, Henry Burchard, M.A., Ph.D. (Leipzig); Professor of Mathematics, Princeton University, Princeton, N. J.

1891, June Finkel, Benjamin Frankuin, M.A., M.Sc.; Editor of the American Mathematical Monthly; Professor of Mathematics and Physics, Drury College, Springfield, Mo. $106 \%$ Clay Street.

1891, Oct. Fisher, George Egbert, M.A., Ph.D.; Assistant Professor of Mathematics, University of Pennsylvania, Philadelphia, Pa.

1895, Jan. Fisher, Irving, B.A., Ph.D. (Yale); Editor of the Yale Review; Assistant Professor of Political Science, Yale University, New Haven, Conn. 460 Prospect Street.

1888, Nov. Fiske, Thomas Scott, M.A., Ph.D. (Columbia); Member of the London Mathematical Society ; Editor of the Bulletin of the American Mathematical Society; Professor of Mathematics, Columbia University, New York, N. Y.

1894, Oct. Flowers, Robert Lee, Graduate of the U. S. Naval Academy ; Professor of Mathematics, Trinity College, Durham, N. C. 
Admission.

1893, Dec. Frankland, Frederick William, F.I.A.; Member of the Actuarial Society of America; Associate Actuary of the New York Life Insurance Company ; 346 Broadway, New York, N. Y.

1892, Dec. Franklin, Fabian, Ph.B., Ph.D. (Johns Hopkins); Member of the London Mathematical Society; 150' Park Avenue, Baltimore, Md.

1895, Jan. Freedman, William Horatio, C.E., E.E.; Associate Editor of Electric Pcwer; Tutor in Mechanics, Columbia University, New York, N. Y.

1897, Mar. Freeland, Williaj, B.A. 2'y W. 44th Street, New York, N. Y.

1895, Nov. Frizell, ArThur Bowes, B.A.; Instructor in Mathematics, Harvard University. 415 Broadway, Cambridge, Mass.

1892, Oct. Gable, George Daniel, M.A., Ph.D.; Hunt Professor of Mathematics, Parsons College, Fairfield, Iowa.

1894, Feb. Gentry, Ruth, B.Ph., Ph.D. (Bryn Mawr); Instructor in Mathematics, Vassar College, Poughkeepsie, N. Y.

1897, Dec. Germann, George B., B.A.; University Fellow in Education, Columbia University, New York, N. Y.

1891, Jan. Gilman, George HuUghton, M.A.; 71 Wall Street, New York, N. Y.

1892, June Glaisher, James Whitbread LEe, M.A., Sc.D.; F.R.S.; F.R.A.S.; Editor of the Messenger of Mathematics and of the Quarterly Journal of Pure and Applied Mathematics; Fellow and Tutor of Trinity College, Cambridge, England.

1891, May GLashan, JoHn CADenhead ; Inspector of Public Schools, School Inspector's Office, Ottawa, Canada.

1896, Nov. Glover, James Waterman, M.A., Ph.D. (Harvard); Instructor in Mathematics, University of Michigan, Ann Arbor, Mich. 1209 South University Avenue.

1897, Oct. Gore, JoHs KInsey, M.A.; Member of the Actuarial Society of America; Actuary of the Prudential Insurance Company, Newark, N. J.

1897, May Granville, William Anthony, B.Ph., Ph.D. (Yale); Instructor in Mathematics, Yale University, New Haven, Conn. $48^{\prime}$ Orange Street.

1891, June Green, Rufus Lot, B.Sc., M.A.; Professor of Mathematics, Leland Stanford Jr. University, Stanford University, Cal.

1897, Oct. * Greenhill, Alfred George, M.A.; F.R.S.; Professor of Mathematics, Artillery College, Woolwich, England. 
Admission.

1893, Dec. Griffiths, IDA, B.A.; 61 Belmont Avenue, Fall River, Mass.

1894, June Gummere, Henry Volkmar, B.Sc., M.A.; P. O. Box 1293, Philadelphia, Pa.

1894, Aug. Hagen, John George, S.J.; Director of the Georgetown College Observatory, Washington, D. C.

1891, Nov. Hall, Asaph, JR., B.A., Ph.D. (Yale); Member of the Astronomische Gesellschaft; Professor of Astronomy and Director of the Observatory, University of Michigan, Ann Arbor, Mich.

1892, Apr. Hall, Tomas Proctor, Ph.D. (Clark); Professor of Physics, Kansas City University, Kansas City, Kan.

1894, Oct. Hallet, George H., M.A., Ph.D.; Instructor in Mathematics, University of Pennsylvania, Philadelphia, $\mathrm{Pa}$. College Hall.

1891, May Halsted, George Broce, M.A., Ph.D. (Johns Hopkins); Member of the Société Mathématique de France; Member of the Circolo Matematico di Palermo; Member of the London Mathematical Society; Professor of Mathematics, University of Texas, Austin, Texas. 240'y Guadalupe Street.

1895, Apr. Hancock, Harris, B.A., Ph.D. (Berlin); Instructor in Mathematics, Chicago University, Chicago, Ill.

1894, Feb. Hardcastle, Frances, Member of the London Mathematical Society. 38 Eaton Square, London, S. W., England.

1891, May HaRkNess, JAMEs, M.A.; Professor of Mathematics, Bryn Mawr College, Bryn Mawr, Pa.

1891, Apr. HART, JAMEs NorRIs, C.E., M.S.; Professor of Mathematics and Astronomy, University of Maine, Orono, Me.

1891, May Hathaway, Arthur Stafford, B.Sc.; Professor of Mathematics, Rose Polytechnic Institute, Terre Haute, Ind. 2106 N. 10th Street.

1898, Aug. Hawkes, Herbert Edwin, B.A.; Instructor in Mathematics, Yale University, New Haven, Conn. 391 Edgewood Avenue.

1894, Aug. Hay, Gustavus, B.A., M.D. (Harvard). 383 Marlborough Street, Boston, Mass.

1895, Nov. Hayes, Ellen, B.A.; Professor of Applied Mathematics, Wellesley College, Wellesley, Mass. P. O. Box 275.

1891, Apr. Heal, William Ephraim, Member of the London Mathematical Society. 1005 Spencer Avenue, Marion, Ind.

1897, Feb. Heys, Paul Renno, B.Sc., Ph.D. (Pennsylvania) ; Instructor in Mathematics and Drawing, Boys' High School, Reading, Pa. 31'y N. 6th Street. 
Date of

Admission.

1892, Dec. Hill, George William, Ph.D., Sc.D. (Cambridge), LL.D. (Columbia, Princeton) ; Ex-President ; Member of the National Academy of Sciences; Foreign Associate of the Royal Astronomical Society ; West Nyack, N. Y.

1895, Nov. Hill, John Ethan, Ph.D. (Clark).

1898, Dec. HImowich, ADolPн A., M.Sc., M.D.; 130 Henry Street, New York, N. Y.

1894, Mar. Hitchcock, Fannie R. M., Ph.D.; Director of the Woman's Graduate Department, University of Pennsylvania, Philadelphia, Pa. 4038 Walnut Street.

1895, Feb. Holgate, Thomas Franklin, M.A., Ph.D. (Clark) ; Professor of Applied Mathematics, Northwestern University, Evanston, Ill. 617 Hamline Street.

1889, June Holladay, Waller, B.Sc., C.E., M.E.; Professor of Mathematics, Cooper Institute; Mathematician of the Equitable Life Assurance Society, 120 Broadway, New York, N. Y.

1891, May Home, Noed Charles Minchin, LL.B. Wescott, Surrey, England.

1891, May Howe, Charles Sumner, M.Sc., Ph.D.; Professor of Mathematics and Astronomy, Case School of Applied Science, Cleveland, Ohio.

1891, May Howe, Herbert Alonzo, M.A., Sc.D.; Member of the Astronomische Gesellschaft ; Director of the Chamberlin Observatory of the University of Denver, University Park, Colo.

1891, May Hulburt, Lorrain Sherman, M.A., Ph.D. (Johns Hopkins) ; Collegiate Professor of Mathematics, Johns Hop. kins University, Baltimore, Md.

1897, Mar. HuRst, GilberT HaRRison JoHn, B.A.; Member of the London Mathematical Society; Fellow of King's College, Cambridge, England; Master at Eton College, Windsor, England.

1891, Apr. Hussey, William J., B.Sc.; Astronomer in the Lick Observatory, Mt Hamilton, Cal.

1896, Nov. Hutchinson, JoHN IRwiN, B.A.; Ph.D. (Chicago); Instructor in Mathematics, Cornell University, Ithaca, N. Y. 1216 Cascadilla Place.

1891, May Hyde, Edwari) Wyluys, C.E.; Associate Editor of the Annals of Mathematics; Professor of Mathematics and Dean of the Academic Faculty, University of Cincinnati, Cincinnati, O. 814 Lincoln Avenue, Station "D."

1891, June Ireland, Oscar Brown, M.A.; Member of the Actuarial Society of America ; Actuary of the Massachusetts Mutual Life Insurance Company, Springfield, Mass. P.O.Box 1608. 
Date of

Admission.

1892, Jan. Jacobus, David S., M.E.; Professor of Experimental Mechanics and Engineering Physics, Stevens Institute of 'Technology, Hoboken, N. J.

1888, Nov. JAcoBy, HARoLd, Ph.D. (Columbia); Member of the Astronomische Gesellschaft; F.R.A.S.; Adjunct Professor of Astronomy, Columbia University, New York, N. Y.

1893, Feb. JAmes, John Nelson, B.A. Halle, Germany, Harz, 48.

1897, Apr. JofFe, S. A., M.S.; Mutual Life Insurance Company of New York, 32 Nassau street, New York, N. Y.

1891, Mar. Johnson, William Woolsey, M.A.; Member of the London Mathematical Society; Professor of Mathematics, U. S. Naval Academy, Annapolis, Md.

1891, Dec. Kenneliy, A. E., D.Sc.; F.R.A.S.; 1420 Chestnut Street, Philadelphia, Pa.

1897, Aug KepPel, Herbert G., M.A.; Member of the Mathematical Society of Amsterdam, Netherlands ; Instructor in Mathematics, Northwestern University, Evanston, Ill. 1914 Orrington Avenue.

1892, Oct. KERR, William Jasper, B.Sc.; President of the Brigham Young College, Logan, Utah.

1891, Apr. Kershner, Jefferson E., M.A., Ph.D. (Yale); Professor Mathematics, Franklin and Marshall College, Lancaster, Pa.

1897, Aug. Keyser, Cassius Jackson, B.Sc., M.A.; Tutor in Mathematics, Columbia University, New York, N. Y.

1891, Dec. Knisely, Alexander, B.Sc.; Logansport, Ind.

1894, Nov. Kleinheksel, JoHn Henry, M.A.; Professor of Mathematics, Hope College, Holland, Mich. 114 East 9th Street.

1894, Apr. Ladue, Pomeroy, B.Sc.; Professor of Mathematics, New York University, New York, N. Y. University Heights.

1893, Dec. Lambert, Preston Albert, M.A.; Assistant Professor of Mathematics, Lehigh University, South Bethlehem, Pa. 215 S. Center Street.

1897, Jan. Landis, William Werdman, M.A.; Professor of Mathematics, Dickinson College, Carlisle, $\mathrm{Pa}$.

1898, Apr. Lanza, Gaetano, B.Sc., C.E., M.E.; Professor of Theoretical and Applied Mechanics, Massachusetts Institute of Technology, Boston, Mass.

1897, May Laves, KuRT, M.A., Ph.D. (Berlin); Member of the Astronomische Gesellschaft; Instructor in Astronomy, University of Chicago, Chicago, Ill.

1889, Dec. Legras, Gustave, B.Sc., M.Sc.; Assistant Professor of Mathematics, College of the City of New York, $1^{\prime y}$ Lexington Avenue, New York, N. Y. 
Date of

Admission.

1892, Feb. Leuschner, Armin Otto, B.A., Ph.D. (Berlin); Member of the Astronomische Gesellschaft; F.R.A.S.; Associate Professor of Astronomy and Geodesy; Director of the Students' Observatory, University of California, Berkeley, Cal. 2011 Bancroft Way.

1891, May Lewis, Charlton Thomas, Ph.D. (New York University); Member of Actuarial Society of America. 34 Nassau Street, New York, N. Y.

1894, June Ling, George Herbert, Ph.D. (Columbia); Instructor in Mathematics, Wesleyan University, Middletown, Conn.

1891, June Loud, Frank Herbert, B.A. Weymouth, Mass.

1891, Apr. Love, JAMes LeE, M.A.; Instructor in Mathematics, Harvard University, Cambridge, Mass. 2' Walter Street.

1894, Oct. LovetT, Edgar Odell, M.A., Ph.D. (Virginia, Leipzig); Editor of the Bulletin of the American Mathematical Society; Assistant Professor of Mathematics, Princeton University, Princeton, N. J.

1896, Nov. Ludlow, Henry Hunt, Graduate of the U. S. Military Academy ; Captain, 6th U. S. Artillery. Fort Wadsworth, Rosebank, Staten Island, N.Y.

1891, June Ludwig, Henry Thomas Jefferson, M.A., Ph.D., Professor of Mathematics, Physics and Astronomy, North Carolina College, Mt. Pleasant, N. C.

1894, Oct. Lyman, Elmer A., B.A.; Professor of Mathematics, Michigan State Normal College, Ypsilanti, Mich., 126 N. Washington Street.

1891, June MCCABE, WilliaM, LL.B.; F.I.A.; Corresponding Member of the Institut des Actuaires Français ; Member of the Actuarial Society of America. 112-118 King Street, W., Toronto, Canada.

1889, Dec. * McClintock, Emory, M.A., Ph.D. (Wisconsin), LL.D. (Columbia); Ex-President ; F.I.A.; Member of the Acturial Society of America ; Member of the London Mathematical Society; Actuary of the Mutual Life Insurance Company of New York. 32 Nas:au Street, New York, N. Y.

1891, May McDougall, Alexander Hiram, B.A.; Mathematical Master of the Collegiate Institute, Ottawa, Canada. 286 Kent Street.

1896, Apr. McGAw, Frederick Mirton, M.A.; Instructor in Mathematics, Bordentown Military Institute, Bordentown, N. J.

1897, Dec. McKay, Alexander Charles, B.A.; Professor of Mathematics, McMaster University, Toronto, Canada.

1895, Nov. McKinney, Thomas Emery, M.A.; Professor of Mathematics and Astronomy, Marietta College, Marietta, $\mathrm{O}$. $61 \%$ Wooster Street. 
Admission.

1892, Oct. McLennan, John Cunningham, B. A.; Assistant Demonstrator in Physics, University of Toronto, Toronto, Canada.

1891, Apr. McMahon, JAMes, M.A.; Member of the London Mathematical Society ; Associate Editor of the Annals of Mathematics; Assistant Professor of Mathematics, Cornell University, Ithaca, N. Y. 1 Quarry Street.

1891, Apr. McNellu, Malcolm, M.A., Ph.D.; Professor of Mathematics and Astronomy, Lake Forest University, Lake Forest, III.

1898, Dec. *Macaulay, Francis Sowerby, M.A., D.Sc. (London); Member of the London Mathematical Society ; Mathematical Master, St. Paul's School, West Kensington, London, W., England.

1891, May Macfarlane, Alexander, M.A., D.Sc. (Edinburgh), LL.D.; Member of the Circolo Matematico di Palermo; Lecturer on Mathematical Physics, Lehigh University, South Bethlehem, Pa.

1897, Dec. Mackay, John Sturgeon, M.A., LI.D.; Fellow of the Royal Society of Edinburgh; Member of the Edinburgh Mathematical Society ; Master in the Edinburgh Academy. 69 Northumberland Street, Edinburgh, Scotland.

1897, Feb. Mackinnon, AnNIE I.ouise, M.S., Ph.D.; Professor of Mathematics, Wells College, Aurora, N. Y.

1888, Nov. MACLAY, JAMEs, C.E.; Instructor in Mathematics, Columbia University, New York, N. Y.

1897, Jan. Maddison, Istber, B.Sc., Ph.D. (Bryn Mawr); Member of the London Mathematical Society; Secretary to the President and Reader in Mathematics, Bryn Mawr College, Bryn Mawr, Pa.

1891, June Magie, William Francis, M.A., Ph.D. (Berlin); Professor of Physics, Princeton University, Princeton, N. J.

1897, Aug. Maltbie, Willtam Henry, M.A., Ph.D. (Johns Hopkins); Associate Professor of Mathematics, The Woman's College, Baltimore, Md.

1891, Nov. Mann, Charles Rrborg, M.A., Ph.D. (Berlin); Associate in Physics, University of Chicago, Chicago, Ill.

1893, Apr. Manning, George Lincoln, M.E., P. O. Box 508, Orange, N. J.

1891, Nov. Manning, Henry Parker, B.A., Ph.D. (Johns Hopkins); Assistant Professor of Pure Mathematics, Brown University, Providence, $R$. I.

1891, June Markley, Joseph Lybrant, M.A., Ph.D. (Harvard) ; Assistant Professor of Mathematics, University of Michigan, Ann Arbor, Mich. 912 Forest Avenue. 
1891, Apr. Martin, Artemas, M.A., Ph.D., LL.D.; Member of the London Mathematical Society; Member of the Société Mathématique de France; Member of the Circolo Matematico di Palermo ; Member of the Edinburgh Mathematical Society ; Editor of the Mathematical Magazine and of the Mathematical Visitor; U. S. Coast and Geodetic Survey Office, Washington, D. C. 1534 Columbia Stret, $N$. $W$.

1893, Feb. Maschke, Heinrich, Ph.D. (Göttingen) ; Associate Professor of Mathematics, University of Chicago, Chicago, Ill. 5\%21 Monroe Avenue.

1890, May Mason, JAmes Weir, M.A.; Member of the Actuarial Society of America ; Professor of Pure Mathematics, College of the City of New York, New York, N. Y.

1892, Mar. Mendizábal-Tamborkel, Joaquin De, M.A., D.Sc., Geographical and Military Engineer; Member of the London Mathematical Society; Member of the Société Mathématique de France, F.R.A.S.; Member of the Astronomische Gesellschaft ; Captain of Engineer Corps ; Sociedad "Alzate," Palma No. 13, Mexico, D. F., Mexico.

1891, Apr. Merriman, Mansfield, C.E., Ph.D.; Professor of Civil Engineering, Lehigh University, South Bethlehem, $\mathrm{Pa}$.

1889, June Messengrer, Hiram John, Litt.B., Ph.D.; Member of the Actuarial Society of America; Actuary of the Travelers Insurance Company, Hartford, Conn.

1891, Oct. Metzler, Wrlliam H., B.A., Ph.D. (Clark); Member of the London Mathematical Society; Francis H. Root Professor of Mathematics, Syıacuse University, Syracuse, N. Y.

1891, June Miller, Bloomfield Jackson, President of the Actuarial Society of America; Mathematician of the Mutual Benefit Life Insurance Company. 752 Broad Street, Newark, N. J.

1891, May Mrlcer, Ephraim, M.A., Ph.D.; Professor of Mathematics and Astronomy, and Dean of the School of Arts, University of Kansas, Lawrence, Kan. 1244 Tennessee Street.

1898, Apr. Miller, G. A., Ph.D.; Instructor in Mathematics, Cornell University, Ithaca, N. Y. 11 Cook Street.

1891, May Moody, William Albion, M.A.; Professor of Mathematics, Bowdoin College, Brunswick, Me.

1891, May Moore, Eliakim Hastings, B.A., Ph.D.; Member of the Circolo Matematico di Palermo; Member of the London Mathematical Society; Member of the Deutsche Mathematiker-Vereinigung; Head Professor of Mathematics, University of Chicago, Chicago, Ill. 
Admission.

1896, May |More, Louis Trenchard, B.Sc., Ph.D. (Johns Hopkins); Lecturer in Physics, University of Nebraska, Lincoln, Neb.

1891, May Morley, Frank, M.A., Sc.D. (Cambridge); Editor of the Bulletin of the American Mathematical Society; Professor of Pure Mathematics, Haverford College, Haverford, Pa.

1898, Oct. MulleN, LoRING BLANCHARD, Ph.D.; Instructor in Mathematics, Central High School, Cleveland, $O$.

1890, Dec. Murray, Daniel Alexander, B.A., Ph.D. (Johns Hopkins); Instructor in Mathematics, Cornell University, Ithaca, N. Y.

1891, June Nagle, James C., M.A., C.E., M.C.E.; Professor of Civil Engineering and Physics, Agricultural and Mechanical College of Texas, College Station, Texas.

1891, June Nelson, AlFred BrIERLEY, M.A., M.D. (University of Pennsylvania); Professor of Mathematics, Centre College, Danville, Ky. 443 Lexington Street.

1895, Dec. Neufeld, Julrus L., E.E.; Instructor in Mathematics, Central High School, Phila., Pa. 1909 South Broad Street.

1891, Nov. Newcomb, Srmon, B.Sc., Ph.D., LL.D.; Ex-President ; Member of the National Academy of Sciences ; Foreign Member of the Royal Society of London ; Foreign Associate of the Institute of France ; Foreign Associate of the Royal Astronomical Society; Associate Editor of the American Journal of Mathematics ; Professor of Mathematics-and Astronomy at Johns Hopkins University; Professor of Mathematics of the U. S. Navy, retired. 16:0 $P$. Street, Washington, D. C.

1891, Oct. Newson, Henry Byron, M.A., Ph.D.; Associate Professor of Mathematics, University of Kansas, Lawrence, Kan.

1891, June Nicholson, James William, M.A., LL.D ; Professor of Mathematics, Louisiana State University and Agricultural and Mechanical College; Baton Rouge, La. 901 Convention Street.

1891, May Nipher, Francis Eugene, M.A.; Professor of Physics, Washington University, St, Louis, Mo.

1895, Feb. Odell, John William, B.A.; Fellow in Mathematics, University of Toronto, Toronto, Canada.

1891, Dec. Olds, George Daniel, M.A.; Professor of Mathematics, Amherst College, Amherst, Mass.

1891, Apr. Osborne, George AbBotr, B.Sc.; Professor of Mathematics, Massachusetts Institute of Technology, Boston, Mass.

1895, Feb. OsGood, William Fogg, M.A., Ph.D. (Erlangen); Assistant Professor of Mathematics, Harvard University, Cambridge, Mass. 
Date of

Admission.

1894, Oct. OsterberG, MAx, E.E., M.A.; 11 Broadway, New York, N. Y.

1897, May Palmié, ANNA Helene, B.Ph. (Cornell); Professor of Mathematics, College for Women, Western Reserve University, Cleveland, O. 56 Mayfield Street.

1894, Mar. Pantridge, Edward Anson, B.Sc., M.A., Ph.D.; Professor of Physics, Central Manual Training School, Philadelphia, Pa. 17th and Wood Streets.

1896, Dec. Patterson, James Lawson, B.Ph., D.Sc. (Princeton) ; Head Master of Chestnut Hill Academy, Chestnut Hill, Philadelphia, Pa.

1896, May Peck, Henry Allen, M.A., Ph.D. (Strassburg); Member of the Astronomische Gesellschaft ; Professor of Astronomy, Syracuse University, Syracuse, N. Y. 30\% Waverly Place.

1891, May Peirce, BenJamin Osgood, Ph.D. (Leipzig); Hollis Professor of Mathematics and Natural Philosophy in Harvard University, Jefferson Physical Laboratory, Harvard University, Cambridge, Mass. 51 Oxford Street.

1898, Oct. Peirce, James Mills, M.A.; Perkins Professor of Astronomy and Mathematics, and Dean of the Faculty of Arts and Sciences, Harvard University, Cambridge, Mass. 4 Kirkland Place.

1898, Oct. Pell, Alexander, Ph.D. (Johns Hopkins); Professor of Mathematics, State University of South Dakota, Vermillion, South Dakota.

1893, Oct. Petregrew, David Lyman ; General Special Agent of the Massachusetts Mutual Iife Insurance Company, Springfield, Mass. P. O. Box 75 , Worcester, Mass.

1892, Oct. Pfister, Joseph Clement, M.A.; Tutor in Mechanics, Columbia University, New York, N. Y.

1891, June Philbrick, Philetus Harvey, M.Sc., C.E.; Chief Engineer of the K. C. W. \& G. R. R., Lake Charles, La.

1896, Nov. Phillips, Andrew Wheeler, M.A., Ph.D. (Yale); Professor of Mathematics and Dean of the Graduate School, Yale University, New Haven, Conn. 209 York Street.

1894, Oct. Prerpont, JAMes, Ph.D. (Vienna); Professor of Mathematics, Yale University, New Haven, Conn. 35\% Howard Avenue.

1889, Dec. Prerson, Israel Correll, M.A., Ph.D.; Secretary and Editor of Papers and Transactions of the Actuarial Society of America; Actuary of the Washington Life Insurance Company of New York. 21 Cortlandt Street, New York, N. Y. 
Date of

Admission.

1892, Nov. Plumley, Gardner Ladd ; Member of the Actuarial Society of America ; Assistant Actuary of the Home Life Insurance Corwpany. 256 Broadway, New York, N. Y.

1890, Dec. Poor, Charles Lane, Ph.D. (Johns Hopkins); Member of the Astronomische Gesellschaft; F.R.A.S.; Associate Professor of Astronomy, Johns Hopkins University, Baltimore, Md.

1897, Feb. Porter, Milton Brockett, B.Sc., M.A., Ph.D. (Harvard); Instructor in Mathematics, University of Texas, Austin, Texas.

1892, May Prentiss, Robert Woodworth, M.Sc.; Professor of Mathematics and Astronomy, Rutgers College, New Brunswick, N. J. 142 Hamilton Street.

1889, Dec. Pupin, Michael Idvorsky, B.A., Ph.D. (Berlin); Adjunct Professor of Mechanics, Columbia University, New York, N. Y.

1891, June Puryear, Charles, B.Sc., M.A., C.E.; Professor of Mathematics, Agricultural and Mechanioal College of Texas, College Station, Texas.

1891, June Putnam, Kendrick S., M.A.; City Chamberlain, Rome, N. Y.

1894, Mar. Rand, John Holmes, M.A.; Professor of Mathematics, Bates College, Lewiston, Me. 28 Frye Street.

1898, Oct. RANum, ARThuR, B.A.; Professor of Mathematics and Astronomy, University of Washington, Seattle, Washington. 1108 Sixth Avenue.

1891, Dec. Rayson, Amy, B.A.; Joint Principal of School for Girls, New York, N. Y. 176 and 180 West 75 th Street.

1888, Nor. Rees, John Krom, M.A., E.M., Ph.D.; Member of the Astronomische Gesellschaft; F.R.A.S.; Professor of Astronomy and Director of the Observatory, Columbia University, New York, N. Y.

1893, Apr. Rice, Charles Moen, B.A.; Worcester, Mass. P. $O$. Box 215.

1891, A pr. Rice, John Minot, B.Sc., Ph.D. (Stevens Institute); Professor of Mathematics of the U. S. Navy, retired ; Northborough, Mass.

1891, Oct. Rock weld, Charles Hald ; Tarrytown, N. Y.

1891, May Rockwood, Charles Greene, JR., M.A., Ph.D. (Yale); Professor of Mathematics, Princeton University, Princeton, N. J. 34 Bayard Lane.

1896, Apr. Roe, Edwarn Drake, M.A., Ph.D. (Erlangen); Associate Professor of Mathematics, Oberlin College, Oberlin, Ohio. 11 Nichols Street, Norwood, Mass. 
Date of

Admission.

1897, Feb. Rothrock, David Andrew, M.A., Ph.D. (Leipzig); Assistant Professor of Mathematics, University of Indiana, Bloomington, Ind.

1898, Aug. SAFFord, Frederick Hollister, M.A., Ph.D. (Harvard); Instructor in Mathematics, Harvard University, Cambridge, Mass. 22 Sacramento Place.

1897, Dec. SAUREL, YAUL LouIs, B.Sc.; Instructor in Mathematics, College of the City of New York. 17 Lexington Avenue, New York, N. Y.

1891, Nov. SAyre, Herbert Armistead, B.E., Ph.D. (Johns Hopkins); Professor of Physics, University of Alabama, University, Ala.

1894, Mar. Schitegel, Victor, Ph.D. (Leipzig); Member of the Société Mathématique de France; Member of the Circolo Matematico di Palermo ; Professor of Mathematics, Königliche Höhere Maschinenbauschule, Hagen, Germany. Volmestrasse 62.

1898, Aug. Schltsinger, Frank, Ph.D. (Columbia). 242 West 135th Street, New York, N. Y.

1892, Feb. Schmiedel, OscAR, B.Sc., M.A.; Professor of Mathematics, Bethany College, Bethany, W. Va.

1895, Mar. Schmitt, Cooper Davis, M.A.; Professor of Mathematics, University of Tennessee, Knoxville, Tenn.

1892, Apr. Schultze, Arthur, Ph.D.; Boys' High School, New York, N. Y.

1893, Oct. SchwatT, IsAac J., Ph.D.; Assistant Professor of Mathematics, University of Pennsylvania, Philadelphia, Pa.

1891, May ScotT, Charlotte ANGAS, D.Sc. (London); Member of the London Mathematical Society ; Member of the Edinburgh Mathematical Society; Member of the Deutsche Mathematiker-Vereinigung; Member of the Circolo Matematico di Palermo; Professor of Mathematics, Bryn Mawr College, Bryn Mawr, Pa.

1889, June Searle, Rev. George Mary, M.A., Ph.D.; 415 W. $59 t h$ Street, New York, N. Y.

1895, Aug. See, Thomas Jefferson Jackson, M.A., Ph.D. (Berlin); Member of the Astronomische Gesellschaft; F.R.A.S.; Astronomer of the Lowell Observatory, Flagstaff, Arizona.

1892, June SHACK, FERdinAND, B.Sc., M.A., LL.B.; Inspector of Common Schools. 56 Wall Street, New York, N. Y.

1891, Apr. Shattuck, SAmuel Walker, B.Sc., M.A., C.E.; Professor of Mathematics, University of Illinois, Champaign, Ill.

1894, Mar. ShAw, JAMes Byrnie, M.Sc., D.Sc.; Department of Mathematics, Michigan Military Academy, Orchard Lake, Mich. 
Date of

Admission.

1894, Jan. ShIElds, JoHn Franklin, B.Sc.; Professor of Mathematics, Adelphi College, Brooklyn, N. Y.

1893, Oct. Smith, David Eugene, Ph.M., Ph.D.; Member of the Deutsche Mathematiker-Vereinigung; Principal of the State Normal School, Brockport, N. Y.

1898, Apr. SMith, Eugene Randolph, A.B., M.A.; Instructor in Mathematics, Syracuse University, Syracuse, N. Y. 724 Comstock Avenue.

1891, May Sмiтh, Otis David, M.A.; Professor of Mathematics, Alabama Polytechnic Institute, Auburn, Ala.

1891, Nov. Smith, Percey Franklyn, Ph.B., Ph.D.; Assistant Professor of Mathematics, Sheffield Scientific School, Yale University, New Haven, Conn. 118 Humphrey Street.

1891, Apr. Smith, William Benjamin, M.A., Ph.D. (Göttingen); Professor of Mathematics, Tulane University, New Orleans, Ia.

1889, Dec. Srook, Thomas Edward, E.M.; Architect and Engineer. 261 Broadway, New York, N. Y.

1895, Apr. Snyder, Monroe Benjamin, M.A.; Professor of Astronomy and Applied Mathematics, Central High School, Philadelphia, Pa. 2402 North Broad Street.

1896, Nov. SNyder, VirgIL, M.A., Ph.D. (Göttingen); Instructor in Mathematics, Cornell University, Ithaca, N. Y. 40 University Avenue.

1892, May Squier, George Owen, Ph.D. (Johns Hopkins); Lieutenant-Colonel, U. S. A. Signal Corps ; First Lieutenant, 3d Artillery, U. S. A.; Manager of the Journal of the U.S. Artillery. Army and Navy Club, Washington, D. C.

1888, Nov. Stabler, Edward Lincoln, M.A., Ph.D. (Columbia); 135 Willow Street, Brooklyn, N. Y.

1894, Nov. Stecker, Henry Freeman, M.Sc., Ph.D.; Instructor in Mathematics, Northwestern University, Evanston, Ill. 829 Emerson Street.

1891, Jan. Steinmetz, Charles Proteus, Electrician, General Electric Company, Schenectady, N. Y.

1891, June Stevens, Moses CoBb, M.A.; Professor of Mathematics, Purdue University, Lafayette, Ind. 11 Waldron Street.

1891, June St. John, Howell WilliaM, Ph.B.; Member of the Actuarial Society of America ; Corresponding Member of Institut des Actuaires Français; Actuary of the Etna Life Insurance Company, Hartford, Conn. P. O. Box 913.

1891, May Stone, Ormond, M.A.; Associate Editor of the Annals of Mathematics; Director of the Leander MoCormick Observatory and Professor of Practical Astronomy, University of Virginia, Charlottesville, Va. 
Date of

Admission.

1897, Feb. Strory, William Edward, B.A., Ph.D. (Leipzig); Member of the London Mathematical Society; Editor of the Mathematical Review; P'rofessor of Mathematics, Clark University, Worcester, Mass.

1895, Dec. Strong, Wendell Melville, M.A., Ph.D. (Yale); Tutor in Mathematios, Yale University, New Haven, Conn. 30\% Welch Hall.

1891, May Taber, Henry, B.Ph., Ph.D. (Johns Hopkins); Member of the London Mathematical Society ; Assistant Professor of Mathematics, Clark University, Worcester, Mass.

1896, Nov. *Tanner, John Henry, B.Sc.; Assistant Professor of Mathematics, Cornell University, Ithaca, N. Y. 7 Central Avenue.

1889, Dec. TATLOCK, JoHN, JR., M.A.; F.R.A.S.; Assistant Actuary of the Mutual Life Insurance Company of New York. $P . O$. Box 194, New York, N، Y.

1891, Apr. TAYLor, JAMes Morford, M.A., LL.D.; Professor of Mathematics, Colgate University, Hamilton, N. Y.

1891, May Taylor, Thomas Ulvan, C.E., M.C.E.; Professor of Applied Mathematics, University of Texas, Austin, Texas.

1891, Apr. Thompson, Henry Dallas, M.A., D.Sc., Ph.D.; Professor of Mathematics, Princeton University, Princeton, N. J. 80 University Place.

1897, Jan. Thornburg, Chardes Lewis, B.Sc., C.E., Ph.D.; Professor of Mathematics and Astronomy, Lehigh University, South Bethlehem, Pa. 308 Packer Avenue.

1895, Nov. Townsend, Edgar Jerome, Ph.B., Ph.M.; Associate Professor of Mathematics, University of Illinois, Champaign, Ill. Göttingen, Germany.

1893, Nov. Turrell, Isa Ac Hodges, Principal of the Fourth District School, Cincinnati, O. 403 Chase Street, North Side.

1894, Aug. Tyler, Harry Walter, B.Sc., Ph.D. (Erlangen); Professor of Mathematics and Secretary of the Massachusetts Institute oi Technology, Boston, Mass.

1897, Dec. UNDerhiLl, MARY, M.Sc.; Instructor in Mathematics, George School, $\mathrm{Pa}$.

1888, Nov. VAN Amringe, J. Howard, M.A., Ph.D., L.H.D., LL.D.; Ex-President ; Professor of Mathematics and Dean of Columbia College, Columbia University, New York, N. Y. 204 W. 44th Street.

1891, June Van Velzer, Charles Ambrose, B.Sc., Ph.D.; Member of the London Mathematical Society ; Professor of Mathematics, University of Wisconsin, Madison, Wis. $134 \mathrm{~W}$. Gorham Street. 
1893, Apr. VAN Vleck, Edward Burr, M.A., Ph.D. (Göttingen)Professor of Mathematics, Wesleyan University, Middle; town, Conn.

1891, Apr. Van Vteck, John Monroe, M.A., LL.D.; Member of the Astronomische Gesellschaft ; Professor of Mathematics and Astronomy, Wesleyan University, Middletown, Conn.

1890, May Von NARDroff, ERnest Robert, E.M.; Head of the Science Department, Erasmus Hall High School, Brooklyn, N. Y.

1891, Oct. WAIt, Lucien Augustus, B.A., Professor of Mathematics, Cornell University, Ithaca, N. Y. 35 East Avenue.

1891, Apr. Waldo, Clarence Abiathar, M.A., Ph.D.; Head Professor of Mathematics, Purdue University, Lafayette, Ind. 113 S. Ninth Street.

1894, Feb. WALKer, LoN CAIN, M.A.; Professor of Mathematics, Montana State Normal School, Dillon, Mon.

1898, Dec. WALKer, Buzz M., B.Sc., M.Sc.; Professor of Mathematics, Mississippi Agricultural and Mechanical College, Agricultural College, Miss.

1898, Apr. Washburne, Alva Courtenay, Actuarial Division, Metropolitan Life Insurance Company. 1 Madison Avenue, New York, N. Y.

1891, Oct. WEBB, JjHN Burkits, C.E.; Professor of Mathematics and Mechanics, Stevens Institute of Technology, Hoboken, N. J.

1891, May Webșter, Arthur Gordon, B.A., Ph.D. (Berlin); Assistant Professor of Physics, Clark University, Worcester, Mass.

1891, June WeEks, Rufus Wells ; Member of the Actuarial Society of America; Actuary of the New York Life Insurance Company. 346 Broadway, New York, N. Y.

1892, Feb. Weld, Laenas Gifford, B.Sc., M.A.; Professor of Mathematics and Astronomy, University of Iowa, Iowa City, Ia.

1891, Apr. Wells, Webster, B.Sc.; Professor of Mathematics, Massachusetts Institute of Technology, Boston, Mass.

1891, May Wentworth, George Albert, M.A.; Exeter, N. H.

1896, Sept. Wentz, Estella Kate, B.Sc., M.Sc.; Instructor in Mathematics, Industrial Training School, Indianapolis, Ind.

1897, Feb. Wernicke, August Ludwig Paux; Professor of Modern Languages, State College of Kentucky, I,exington, $\mathrm{Ky}$. $10^{\prime \prime}$ East Maxwell Street.

1897, Dec. * Western, Alfíed Edward, B.A.; Member of the London Mathematical Society. 36 Lancaster Gate, London, W., England. 
Date of

Admission.

1898, Aug. Westlund, JAcoB, Ph.D. (Yale); Instructor in Mathematics, Yale University, New Haven, Conn. 218 Mansfield Street.

1892, Nov. White, Henry Seely, B.A., Ph.D. (Göttingen); Noyes Professor of Pure Mathematics, Northwestern University, Evanston, Ill. P. O. Box 244 .

1898, Oct. Whitehead, Alfred Worth, M.A.; Fellow and Lecturer, Trinity College, Cambridge, England.

1891, June Whitney, Mary Watson, M.A.; Professor of Astronomy and Director of the Observatory, Vassar College, Poughkeepsie, N. Y.

1897, Dec. *WhitTaker, Edmund Taylor, B.A.; Member of the Lon don Mathematical Society ; F.R.A.S.; Fellow and Lecturer of Trinity College, Cambridge, England.

1897, Feb. Whittemore, JAMes Kelsey, B.A., M.A.; care of Messrs. Brown, Shipley \& Co., Founders Court, London, E. C., England.

1890, Oct. Wiley, George Langford, M.A.; New York Life Insurance Company. 346 Broadway, New York, N. Y.

1892, May Willard, Joskph Moody, B.A.; Professor of Mathematics, Pennsylvania State College, State College, Pa. Oxford, N. $H$.

1895, May Williams, Clark Benedict, M.A.; Olney Professor of Mathematics, Kalamazoo College, Kalamazoo, Mich. 703 W. South Street.

1892, May Williams, Ella Connelra, M.A. 146 W. 64th Street, New York, N. Y.

1898, Apr. Williams, William Hill, M.A.; Chair of Mathematics, Wisconsin State Normal School, Platteville, Wis.

1891, May Willson, Frederick Newton, M.A., C.E.; Professor of Descriptive Geometry, Stereotomy and Technical Drawing, John C. Green School of Science, Princeton University, Princeton, N. J. P. O. Box 641 .

1897, Jan. Winston, Mary Frances, B.A., Ph.D. (Göttingen); Professor of Mathematics, Kansas State Agricultural College, Manhattan, Kansas. P. O. Box 414.

1895, Oct. Woods, Frederick S., B.A., Ph.D. (Göttingen); Assistant Professor of Mathematics, Massachusetts Institute of Technology, Boston, Mass.

1891, May Woodward, RoberT Simpson, C.E., Ph.D.; Associate Editor of the Annals of Mathematics; Associate Editor of Science; Professor of Mechanics and Mathematical Physics and Dean of the School of Pure Science, Columbia University, New York, N. Y.

1891, May Worrhen, Thomas Wilson DorR, M.A.; Professor of Mathematics, Dartmouth College, Hanover, N. H. 
Date of

Admission.

1898, Oct. Wright, Walter Channing, Member of the Actuarial Society of America ; Actuary of the New England Mutual Life Insurance Company. 134 Congr، ss Street, Boston, Mass.

1891, May Young, Jacob William Albert, M.A.; Assistant Professor of Mathematical Pedagogy, University of Chicago, Chicago, Ill. 5758 Washington Avenue.

1893, Mar. Yowels, Everetr Irving, C.E., M.Sc.; Assistant at the Cincinnati Observatory, Cincinnati, $\mathrm{O}$.

1891, June Zerr, George B. MCClellan, M.A., Ph.D.; Head of Science Department, Chester High School, Chester, Pa.

1891, Apr. Ziwet, AlEXANDer, C.E.; Editor of the Bulletin of the American Mathematical Society; Junior Professor of Mathematics, University of Michigan, Ann Arbor, Mich. Care of Morgan, Harjes \& Co., 31 Boulevard Haussman, Paris, France.

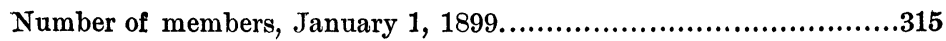

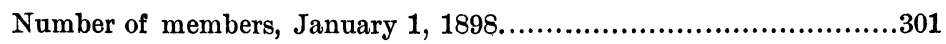

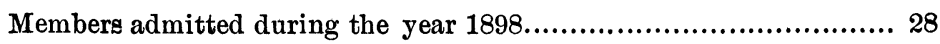

Members withdrawing during the year 1898 .............................. 14 